\title{
Social support for patients undergoing liver transplantation in a Public University Hospital
}

\author{
Clerison Stelvio Garcia ${ }^{1,5^{*}}$, Agnaldo Soares Lima², Ehideé Isabel Gómez La-Rotta ${ }^{3}$ \\ and Ilka de Fátima Santana Ferreira Boin ${ }^{4}$
}

\begin{abstract}
Background: Several diseases may lead to the need for liver transplantation due to progressive organ damage until the onset of cirrhosis, resulting in changes in interpersonal relationships. Social Support for transplant candidates is an important variable, providing them with psychological and social well-being. This study aims to assess social support in chronic hepatic patients, waiting for liver transplantation.

Methods: A cross-sectional study was conducted with 119 patients, for convenience sampling, from the liver transplant waiting list at a Brazilian University Hospital Outpatients. The information was collected through semistructured questionnaires, in four stages: 1) socioeconomic and demographic information 2) clinical aspects 3) feelings 4) Social Support Network Inventory (SSNI), to Brazilian Portuguese. The statistical analysis was conducted using ANOVA and multivariate linear regression analysis to evaluate the relationship between the scales of social support and the collected co-variables.
\end{abstract}

Results: Average age was $50.2 \pm 11.6$, and 87 (73.1\%) were men. Patients with alcohol and virus liver disease etiology had the same frequency of $28 \%$. The MELD, without extrapoints, was $16.7 \pm 4.9$. Global social support family score was $3.72 \pm 0.39$, and Cronbach's alpha $=0.79$. The multivariate analysis presented the following associations, age $=[-0.010(95 \% \mathrm{Cl}=-0.010--0.010) ; P=0.001]$, etiology of hepatic disease $=[-0.212(95 \% \mathrm{Cl}=-$ $0.37--0.05) ; P=0.009]$, happiness $=[-0.214(95 \% \mathrm{Cl}=-0.33--0.09) \mathrm{P}=0.001)$ and aggressiveness $=[0.172(95 \% \mathrm{Cl}=$ $0.040-0.030) ; P=0.010$ ).

Conclusions: The social support was greater when the patients were younger (18 to 30 years). Patients with alcoholic cirrhosis, regardless of whether or not they were associated with virus, had less social support. As for feelings, the absence of happiness and the presence of aggressiveness showed a negative effect on social support.

Keywords: Liver transplant, Social support, Psychosocial aspects

\section{Background}

Liver transplantation is aimed at reestablishing the chronic hepatopathy of a patient's extremely depleted baseline health status [1]. The main indications for hepatic transplantation today are cirrhosis induced by hepatitis $C$ virus and alcohol abuse [2, 3]. However, before transplantation, chronic poor prognosis

\footnotetext{
* Correspondence: clerison_garcia@yahoo.com.br

${ }^{1}$ Faculty of Medicine, Federal University of Minas Gerais, Belo Horizonte, Brazil

${ }^{5}$ Faculty of Medical Sciences, State University of Campinas, Campinas, Brazil

Full list of author information is available at the end of the article
}

hepatopathy can lead to painful consequences, affecting the whole family unit [4].

Such a critical moment brings on feelings concerning life continuity, families face the loss of normal life and the family dissolution myth that fatal diseases only happen to others [5]. In addition, daily family life undergoes sudden changes; parents, siblings, spouses and relatives are suddenly uprooted from their domestic ordinary activities and thrown into a strenuous routine of medical appointments, examinations and other medical procedures, which create an atmosphere of uneasiness, uncertainty and instability [5]. 
For this reason, it is fundamental the social support formed by bonds established in social life. It is considered an interpersonal phenomenon expressed through care, trust reassurance and personal merit of the individual's self-esteem $[6,7]$. People who are actually linked by affection, consideration and trust may positively impact the patient's behavior and perception while waiting for the transplantation procedures [8]. Psychological and physical resources can favor the patient's enabling them to successfully face the difficulties encountered, when reciprocal help and information are developed for the patient's needs [9].

The importance of social support has been recognized in coping with stress. This support is associated with several other measures, such as health treatment adherence, control perception, sense of stability and psychological well-being. There is also evidence that social support reduces stressful event impacts [10]; it provides better physical and mental health effects, closely related to well-being [11]. It is a multidimensional concept, which refers to the material and psychological resources to which people have access through their social networks [12].

Social support is a crucial health variable although there is no uniformity in the way it is measured, nor the relationship between the different strategies and techniques used to evaluate it. The variety of these social support techniques show the complexity of the concept but none of them have yet focused on social support entirely [13].

The social support network inventory (SSNI) has not been applied in patients indicated for liver transplantation yet. This instrument had already been used to evaluate social support in patients with breast cancer, eating disorders, bipolar disorder and other chronic diseases [14-19].

Thus, this study aims to assess social support perception in chronic hepatopathy patients, on a liver transplantation waiting list.

\section{Methods}

\section{Study design}

A cross-sectional study was conducted from October 2010 to September 2011 with patients on a liver transplantation waiting list at a Brazilian public university hospital that belongs to SUS (Brazilian Public Health System).

\section{Study population and sample studied}

One hundred and nineteen patients as convenience sample in that period were considered for study belonging to the Outpatients at the Unit of Liver Transplantation at the Alfa Institute of Gastroenterology Departament, Federal University of Minas Gerais, Brazil.
The sample selection was performed for convenience, following the order of transplant patients, three times a week in the period of study. Participants were selected according to inclusion criteria: outpatients, over 18 years of age, diagnosed with chronic liver disease. Exclusion criteria were patients with indication for simultaneous liver and kidney transplantation as well as retransplantation candidates. The interviews were conducted only by a psychologist researcher.

This study was approved by the Research Ethics Committee (COEP) of the Federal University of Minas Gerais (UFMG) $n^{\circ}$. ETIC: 234-10. All participants in this study understood the purpose of the study, agreed with it and signed the Informed Consent Term.

\section{Data collection}

The information was collected through a semistructured questionnaire; 1) socioeconomic and demographic information (age, gender, marital status, education level, average monthly family income and labour status); 2) clinical aspects (MELD, etiology of hepatic disease, concomitant disease, encephalopathy and psychiatric disorder); 3) Feelings (anxiety, happiness and aggressiveness) and 4) Social Support Network Inventory (SSNI) [15] adapted to Brazilian Portuguese [14], consisting of 5 dimensions with 10 QSS (questions of social support) that are described in Table 1. QSS from 1 to 9 were classified in five scores (1:never, 2:almost never, 3:sometimes, 4:frequently and 5:always) and question 10 in six scores (1:I did not contact this person, 2:the support did not help, 3:I did not feel support, 4:I felt little support, 5:I felt good support and 6:I felt a lot of support).

Participants identify people or groups to whom they feel close and who provide specific components of support. Using this partial network list, they are asked to choose five persons, or four and one group from the list, who provide the most support [15].

The scores are computed for each subscale and an overall mean is calculated for each of the five persons identified by the respondent [15]. The tools have 10 items, each scored from 0 to 5 . Higher score represents higher levels of perceived support [15].

\section{Statistical analysis}

The database was compiled and the statistical analysis was conducted using the Statistical Package for the Social Sciences (SPSS) software, version 12.0 (SPSS, Chicago, IL).

We carried out the Shapiro-Wilk tests to determine the type of distribution of the scale. Cronbach's alpha ( $(\boldsymbol{\alpha})$ test was used and descriptive statistics and ANOVA were applied.

Initially, the scale was compared with the co-variables collected using simple linear regression analysis. 
Table 1 Dimensions and questions of Social Support Network Inventory [15]

\begin{tabular}{lll}
\hline Dimensions & Social Support & Questions Social Support \\
\hline Expression of positive affection & QSS3 - (intimacy) & How close are you to this person? \\
& QSS8 - (feel valued) & How often do you feel valued and appreciated? \\
Expression of agreement & QSS6 - (receive support) & How often do you receive emotional support from this person? \\
& QSS7 - (give support) & How often can you give social support? \\
Assistance & QSS2 - (availability) & How available is this person to you? \\
Material and economic help & QSS10 (support in disease) & How much support did you receive in the disease? \\
& QSS4 - (receive assistence) & How often to do you receive practical assistance from this person? \\
Social integration & QSS5 - (giver assistance) & How often does this person give practical assistance? \\
& QSS9 - (direction in life) & How often does this person gives life guidance? \\
\hline
\end{tabular}

QSS questions of social support

Multivariate linear regression analysis was used to evaluate the relationship between the social support and the collected co-variables (independent variables). The statistical significance was $P<0.05$.

\section{Results}

\section{Demographic and clinical characteristics}

The current status of these patients' care is described in Fig. 1. The characterization of the patients is described in Table 2. The average age was $50 \pm$ 12 years. Only $13.6 \%$ of the patients were working. Forty-four percent of the patients had an average monthly family income between about US\$ 2016.505041.25 , at the time of collection.
The MELD score of the patients was $16.5 \pm 4.8$ and $44 \%$ had encephalopathy.

The etiology of hepatic disease of the others (29\%) were autoimmune hepatitis cirrhosis, primary biliary cirrhosis, hepatocellular carcinoma, primary sclerosing cholangitis and cryptogenic cirrhosis.

\section{Social support}

Social Support Network Interview (SSNI) showed $3.72 \pm$ 0.39 points with Cronbach's alpha ( $\alpha)$ of 0.798 (Table 3 ), considered moderate.

The analysis using associated factors was: age $=[-0.010$ (95\% CI $=-0.010--0.010) ; P=0.001]$, etiology of hepatic disease $=\left[\begin{array}{lll}-0.212(95 \% \mathrm{CI}=-0.37-0.05) ; P=0.009\end{array}\right]$, happiness $=\left[\begin{array}{lll}-0.214(95 \% \mathrm{CI}=-0.33 \quad-0.09) \quad \mathrm{P}=0.001)\end{array}\right.$

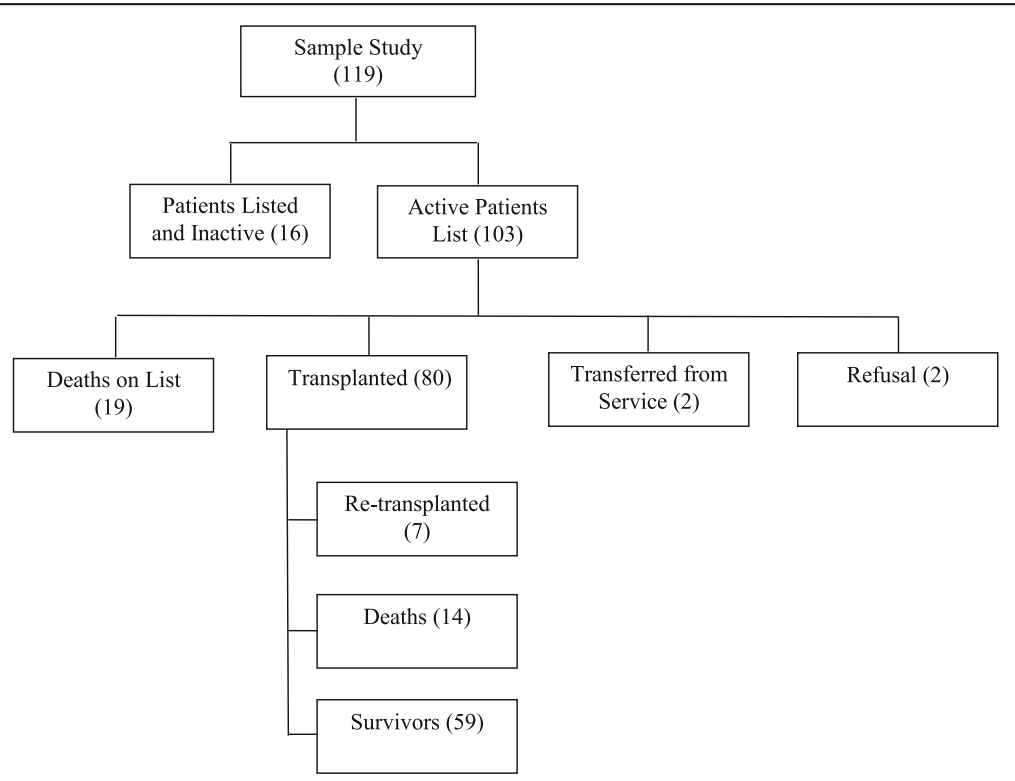

Fig. 1 Flowchart of the recruitment of the evaluated patients and final outcome 
Table 2 Clinical and demographic characterizations of patients the liver transplantation waiting list

\begin{tabular}{|c|c|c|}
\hline Variable & Number & Perceptual (\%) \\
\hline \multicolumn{3}{|l|}{ Gender } \\
\hline Male & 87 & 73.1 \\
\hline Female & 32 & 26.9 \\
\hline \multicolumn{3}{|l|}{ Age group } \\
\hline From 18 to 30 years old & 12 & 10.1 \\
\hline From 30 to 50 years old & 47 & 39.5 \\
\hline$>50$ years old & 60 & 50.4 \\
\hline \multicolumn{3}{|l|}{ Education level } \\
\hline Elementary school & 71 & 59.7 \\
\hline High school & 34 & 28.6 \\
\hline University & 12 & 10.1 \\
\hline Post- graduation & 2 & 1.7 \\
\hline \multicolumn{3}{|l|}{ Marital status } \\
\hline Single & 12 & 10.1 \\
\hline Married & 83 & 69.7 \\
\hline Divorced & 17 & 14.3 \\
\hline Widow (er) & 7 & 5.9 \\
\hline \multicolumn{3}{|l|}{ Labor status } \\
\hline Unemployed & 20 & 16.8 \\
\hline Working & 16 & 13.6 \\
\hline Retired & 54 & 45.4 \\
\hline On sick leave & 29 & 24.4 \\
\hline \multicolumn{3}{|l|}{ Encephalopathy } \\
\hline Yes & 53 & 44.5 \\
\hline No & 66 & 55.5 \\
\hline \multicolumn{3}{|l|}{ Psychiatric Disorder } \\
\hline Yes & 14 & 11.8 \\
\hline No & 105 & 88.2 \\
\hline \multicolumn{3}{|l|}{ Etiology of hepatic disease } \\
\hline Alcohol & 33 & 27.7 \\
\hline Viral hepatitis & 33 & 27.7 \\
\hline Alcohol + Viral hepatitis & 19 & 16.0 \\
\hline Others & 34 & 28.6 \\
\hline Total & 119 & 100 \\
\hline
\end{tabular}

and aggressiveness $=\left[\begin{array}{lll}0.172 & (95 \% \quad \mathrm{CI}=0.040-0.030)\end{array}\right.$ $P=0.010)$, are described in Table 4 .

The social support was higher when the patients were younger (18 to 30 years). Patients waiting for hepatic transplantation due to alcoholic cirrhosis, regardless of whether or not they are associated with viral hepatitis, had lower social support. As for feelings, it was found that the absence of happiness had a lower social support and the presence of aggressiveness, showed a negative effect on social support.
Table 3 Response frequency, mean and Cronbach's alpha of the social support instrument

\begin{tabular}{lllllllll}
\hline Questions & \multicolumn{3}{l}{ \% Answers } & \multicolumn{7}{c}{ Mean \pm SD } & a \\
\cline { 2 - 7 } & 1 & 2 & 3 & 4 & 5 & 6 & & \\
\hline QSS1 & 2.2 & 6.4 & 10.9 & 23.7 & 56.8 & - & $4.3 \pm 0.61$ & 0.806 \\
QSS2 & 1.3 & 9.9 & 19.3 & 36.6 & 32.8 & - & $3.9 \pm 0.57$ & 0.769 \\
QSS3 & 0.7 & 12.8 & 24.9 & 27.2 & 34.5 & - & $3.8 \pm 0.57$ & 0.794 \\
QSS4 & 11.8 & 13.8 & 26.7 & 25.0 & 22.7 & - & $3.3 \pm 0.71$ & 0.788 \\
QSS5 & 23.9 & 25.9 & 21.5 & 17.6 & 11.1 & - & $2.7 \pm 0.84$ & 0.786 \\
QSS6 & 2.4 & 11.8 & 20.0 & 38.7 & 27.2 & - & $3.8 \pm 0.59$ & 0.767 \\
QSS7 & 7.4 & 20.3 & 32.8 & 23.5 & 16.0 & - & $3.2 \pm 0.68$ & 0.767 \\
QSS8 & 1.2 & 2.9 & 14.6 & 39.3 & 42.0 & - & $4.2 \pm 0.52$ & 0.762 \\
QSS9 & 15.6 & 27.4 & 30.4 & 17.3 & 9.2 & - & $2.8 \pm 0.79$ & 0.771 \\
QSS10 & 1.3 & 0.3 & 3.0 & 6.6 & 29.9 & 58.8 & $5.4 \pm 0.56$ & 0.794 \\
SSNI & - & - & - & - & - & - & $3.7 \pm 0.39$ & 0.798 \\
\hline
\end{tabular}

QSS Social Support Questions: Frequency 1-5 (questions 1-9) and Frequency 1-6 (question 10), SSNI Global Social Support Network Inventory, a Cronbach's alpha coefficient, SD Standard deviation

\section{Discussion}

Sociodemographic characteristics

The sociodemographic characteristics of the study population were representative of the general casuistic of the service and did not differ from other authors in the literature found in the mean age $[20,21]$ and in the distribution by gender $[3,22]$. The patient family situation was also similar to that of other publications [23], with the majority of the participants being married in $69.7 \%$ of the cases and studying only at elementary school (59.7\%), which resembled the study by Ferreira et al., which showed 58.5\% [24].

The etiology of hepatic disease was ethylism and viral hepatitis with a frequency of $28 \%$ each, similar to that found in other reports [2, 3]. Only $11 \%$ of the patients worked, differently from another Brazilian sample with a greater number of patients at work [25]. A World Health Organization [26] report showed a higher alcohol consumption among men with a consequent increase in cases of liver cirrhosis. In 2010, Brazil had alcohol consumption of 19.61 per capita/year among men (15 years of age or older) and 8.9 among women [26, 27].

The consequences of alcohol abuse on the health of the population are related to the morbidity shown in $8.1 \%$ of males and $3.2 \%$ of females and a high rate of death due to ethanol-induced liver cirrhosis, estimated at approximately $28.8 / 100,000$ for males and 5.8/100,000 for women every 15 years [26].

In our study, ethanol-induced liver cirrhosis was the disease which had the highest number of indications for transplantation, followed by viral hepatic diseases, more common in men who also had low socioeconomic level (reduced family income and low educational level). These results were reported by WHO, 2011 [26]. The 
Table 4 Associated factors connected to social support score on the liver transplantation waiting list

\begin{tabular}{|c|c|c|c|c|c|c|}
\hline \multirow[b]{2}{*}{ Variables } & \multicolumn{3}{|c|}{ Univariate analysis } & \multicolumn{3}{|c|}{ Multivariate analysis } \\
\hline & $\beta$ & $95 \% \mathrm{Cl}$ & $P$-value & adjusted $\beta$ & $95 \% \mathrm{Cl}$ & $P$-value \\
\hline \multicolumn{7}{|l|}{ Gender } \\
\hline \multicolumn{7}{|l|}{ Female } \\
\hline Male & -0.043 & $-0.19-0.11$ & 0.574 & & & \\
\hline Age (years) & -0.011 & $-0.01--0.06$ & 0.001 & -0.010 & $-0.01--0.01$ & 0.001 \\
\hline \multicolumn{7}{|l|}{ Age } \\
\hline $18-30$ & 0 & & & & & \\
\hline $30-50$ & -0.359 & $-0.55--0.16$ & 0.001 & & & \\
\hline$>50$ & -0.427 & $-0.59--0.26$ & 0.001 & & & \\
\hline
\end{tabular}

Education level

Elementary school

High School

University

Postgraduate

Marital Status

$$
\text { Single }
$$

Married

Divorced

Widow (er)

Labor status

Unemployed

Working

Retired

On sick leave

Encephalopathy

Yes

Not

Psychiatric Disorder

Yes

Not

Etiology of Hepatic disease

$$
\text { Alcohol }
$$

Viral Hepatitis

Alcohol + Viral Hepatitis

Others

Concomitant Disease

Yes

Not

Anxiety

Yes

Not

Happiness

Yes

Not
0

0.20

0.442

0.074

$0.04-0.36$

$0.30-0.58$

$-0.40--0.55$

0.013

0.001

0.763

0

$-0.064$

$-0.27-0.15$

0.548

$-0.177$

$-0.47-0.12$

0.241

$-0.148$

$-0.41-0.11$

0.262

0

0.061

$-0.21-0.34$

0.665

$-0.105$

$-0.30-0.09$

0.293

0.009

$-0.22-0.24$

0.940

0

0.132

$-0.01-0.27$

0.061

\section{0}

0.183

$-0.01-0.37$

0.059

$-0.227$

$-0.40--0.06$

0.009

$-0.212$

$-0.37--0.05$

$-0.29-0.03$

0.224

0.133

$0.39--0.02$

$-0.207$

$-0.289$

$0.50--0.09$

0.005

0

0

0.155

$0.02-0.29$

0.025

0

0.019

$-0.12-0.16$

0.790 
Table 4 Associated factors connected to social support score on the liver transplantation waiting list (Continued)

\begin{tabular}{|c|c|c|c|c|c|c|}
\hline \multirow[b]{2}{*}{ Variables } & \multicolumn{3}{|c|}{ Univariate analysis } & \multicolumn{3}{|c|}{ Multivariate analysis } \\
\hline & $\beta$ & $95 \% \mathrm{Cl}$ & $P$-value & adjusted $\beta$ & $95 \% \mathrm{Cl}$ & $P$-value \\
\hline \multicolumn{7}{|c|}{ Aggressiveness } \\
\hline Yes & 0 & & & & & \\
\hline Not & 0.177 & $0.04-0.31$ & 0.011 & 0.172 & $0.040-0.030$ & 0.010 \\
\hline
\end{tabular}

$\mathrm{Cl}$ confidence interval

Bold numbers represent a associative between the variable and the social support

severity of liver disease, as measured by MELD without extrapoints, obtained a median of 16 (6-34), which is similar to other transplantation services [22].

In the present study, $44.5 \%$ had encephalopathy, ranging from 1 to 18 episodes of encephalopathy per month, a very high incidence when compared with other studies [28], possibly because the incidence and prevalence of hepatic encephalopathy are related to the severity of the hepatic insufficiency $[29,30]$.

\section{Social support}

The term social support is multidimensional and presents different aspects to be analyzed. Social support is a variable of great relevance for health although there is neither uniformity nor clarity to measure it, and no instrument alone has been able to contemplate social support in its entirety $[8,31]$.

We found low social support score (3.72) among patients, especially when compared to studies performed with patients after heart and liver transplantation (4.4 and 4.2) [11], diabetes (4.87) [16] and catheterization of the bladder (4.7) [17]. It is believed that low social support may be related to alcoholrelated liver disease associated with viral hepatitis or alone, observed of $43.7 \%$ in our study.

\section{Sociodemographic and clinical characteristics associated with social support}

Regarding sociodemographic, clinical and social support characteristics, it was observed that age, etiology of hepatic disease, feelings of happiness and aggressiveness were factors that significantly influenced social support.

Social support was higher when the age of the patients was lower (18-30 years), probably due to the fact that younger patients had parents - an important source of social support. This finding is corroborated by Gomeset al. [16], showing that parents or family members are responsible for the most frequent citations of social support, in $82.1 \%$ of the cases.

The greater the education, the greater the access to information, the greater the resources to look for care and the greater the knowledge about the disease and its complications. Therefore, the patient is better able to seek and promote social support [16]. Hence the importance of health professionals to inform, guide and promote a patient's follow-up with indication of transplantation.

Concerning the relationship between social support and the cause of indication for liver transplantation, it was observed that patients with indication for hepatic transplantation due to chronic alcohol abuse had less social support also caused by family attrition [32]. Sometimes the relatives had to help the patient in the streets, strongly encouraging the patient to abandon alcohol dependence and even tolerating conflicts or aggression. When alcoholic patients are indicated for liver transplantation and need care, they are faced with broken, unrelated family situations without the wish to provide adequate social support. This observation is corroborated by Telles-Correia and Mega [32], who report that the alcoholic causes personal and family suffering such as relapses, generating low expectations and disbelief.

When the patient becomes abstemious this favors the health professionals to use feasible procedures and also increases the interest of the family caregivers, thus generating positive effects in the family unit $[32,33]$. The same author also states that relatives show their pain, suffering, discouragement, pity, discomfort and a feeling of impotence with a decrease or suspension of social support [32]. Inadequate social support is particularly associated with diseases that require more care and generate high levels of stress. The obligation to care for family members with alcohol disorders may have been nonnegotiated and even compulsory. These are options which are onerous and are an immeasurable burden in their lives [34, 35].

Patients with hepatic impairment take less medication than when they are associated with concomitant diseases that require complex care which overloads the family. These changes in the family routine increase when a progressive and severe disease causes the family to clash especially when the patient's disabilities increase continuously until the transplantation or death. Increasing stress on caregivers is caused by the risk of exhaustion and the addition of the patient's symptoms and new tasks over time. The discomfort in the family group generates higher levels of stress and, consequently, less social support [36, 37].

In the present study, it was highlighted that patients with feelings of happiness had greater social support. It 
seems incompatible to have joy and to be sick, but it does not have to be this way. Physical malaise generates mental fatigue and tends to be confused with sadness. People with joy, even if ill, think willingly and optimistically about their lives, their health, and believe in science and its advances, trust professionals and their indications and, above all, believe in healing.

The demand for care while patients wait for transplantation often makes it difficult for family members, frustrates professional plans, generates financial difficulties and can cause guilty situations, which results in aggressiveness among patients and caregivers $[37,38]$. All elements of this process are at high levels of anxiety. Young et al. in their study concluded that the patient's family mood could harm the patient [39]. Santos et al. suggest the hypothesis that aggression is favored by leisure, in the pre-term period, while waiting for liver transplantation [40].

The intention of the present study is to favor the medical and psychological monitoring of patients who are candidates for hepatic transplantation and generate greater resources for psychological and multidisciplinary interventions focused on the global patient care.

Following on we will perform a new study comparing populations of pre and post liver transplant periods.

\section{Conclusion}

Social support was less when the patient complains, when the aid relationship failed, when knowledge for long-term care was lacking and also when there was a lack of division of labor.

Social support was greater when patients was young, had the feeling of happiness and absence of aggressiveness. Patients who are candidates for liver transplantation due to ethanol-induced liver disease received less social support.

\section{Abbreviations}

MELD: Model for end-stage liver disease; QSS: Questions of social support; CI: Confidence Interval; SD: Standard deviation; SPSS: Statistical package for social science: SSNI: Social Support Network Inventory, to Brazilian Portuguese; UFMG: Federal University of the Minas Gerais

\section{Acknowledgments}

We are grateful to all patients and families participating in the study, to the Clinic Hospital of the Federal University of Minas Gerais for cooperation,

\section{Funding}

Funders had no role in the design, analysis or writing of this article. Minas Gerais Research Support Foundation (FAPEMIG) which awarded a scholarship to C.S.G (Master's Degree, Graduate Program in Surgery Sciences).

\section{Availability of data and materials}

The dataset(s) supporting the conclusions of this article is (are) included within the article.

\section{Authors' contributions}

CSG, ASL and EIGL participated in the protocol design, participated in fund raising, analysis of results, interpretation of results, prepared the manuscript draft and corrected the final version of the manuscript. IFSFB participated in the protocol design, fund raising, analysis of results, and final review of the manuscript. Finally, all authors reviewed and approved the final version of the manuscript. This article is part of the Master degree essay results.

\section{Ethics approval and consent to participate}

This study was conducted according to the guidelines laid down in the Declaration of Helsinki and all procedures involving human individuals were approved by the Federal University of Minas Gerais ethics committee through $n^{\circ}$ 0234.0.203.000-10. All participants provided written informed consent prior to inclusion in the surveys.

\section{Consent for publication}

Not applicable.

\section{Competing interests}

The authors declare that they have no competing interests.

\section{Publisher's Note}

Springer Nature remains neutral with regard to jurisdictional claims in published maps and institutional affiliations.

\section{Author details}

${ }^{1}$ Faculty of Medicine, Federal University of Minas Gerais, Belo Horizonte, Brazil. ${ }^{2}$ Faculty of Medicine - Federal University of Minas Gerais - Unit of Liver Transplantation at the Alpha Institute Gastroenterology Department, Belo Horizonte, Brazil. ${ }^{3}$ Collective Health, State University of Campinas, Campinas, Brazil. ${ }^{4}$ Unit of Liver Transplantation at the State University of Campinas, Campinas, Brazil. ${ }^{5}$ Faculty of Medical Sciences, State University of Campinas, Campinas, Brazil.

Received: 20 June 2017 Accepted: 7 February 2018

Published online: 17 February 2018

\section{References}

1. O'Grady J. Liver transplantation for acute liver failure. Best Pract Res Clin Gastroenterol. 2012;26(1):27-33. https://doi.org/10.1016/j.bpg.2012.01.012.

2. Adam R, Karam V, Delvart V, O'Grady J, Mirza D, Klempnauer J, et al. Evolution of indications and results of liver transplantation in Europe. A report from the European liver transplant registry (ELTR). J Hepatol. 2012; 57(3):675-88. https://doi.org/10.1016/j.jhep.2012.04.015.

3. Wong RJ, Aguilar M, Cheung R, Perumpail RB, Harrison SA, Younossi ZM, et al. Nonalcoholic steatohepatitis is the second leading etiology of liver disease among adults awaiting liver transplantation in the United States. Gastroenterology. 2015;148(3):547-55. https://doi.org/10.1053/j.gastro.2014.11.039.

4. Annema C, Roodbol PF, Van den Heuvel ER, Metselaar HJ, Van Hoek B, Porte $\mathrm{RJ}$, et al. Trajectories of anxiety and depression in liver transplant candidates during the waiting-list period. Br J Health Psychol. 2017;22(3):481-501. https://doi.org/10.1111/bjhp.12241.

5. Wise BV. In their own words: the lived experience of pediatric liver transplantation. Qual Health Res. 2002;12(1):74-90. https://doi.org/10.1177/ 104973230201200106.

6. Kaplan BH, Cassel JC, Gore S. Social support and health. Med Care. 1977; 15(5):47-58.

7. Finfgeld-Connett D. Clarification of social support. J Nurs Scholarsh. 2005; 37(1):4-9. https://doi.org/10.1111/j.1547-5069.2005.00004.x.

8. Langford CPH, Bowsher J, Maloney JP, Lillis PP. Social support: a conceptual analysis. J Adv Nurs. 1997;25:95-100. https://doi.org/10.1046/j.1365-2648. 1997.1997025095.x.

9. Delgado JF, Almenar L, González-Vilchez F, Arizón JM, Gómez M, Fuente L, et al. Health-related quality of life, social support, and caregiver burden between six and 120 months after heart transplantation: a Spanish multicenter cross-sectional study. Clin Transpl. 2015;29(9):771-80. https://doi. org/10.1111/ctr.12578.

10. Ordin YS, Karayurt Ö. Effects of a support group intervention on physical, psychological, and social adaptation of liver transplant recipients. Exp Clin Transplant. 2016;14(3):329-37.

11. Langenbach M, Schmeisser N, Albus C, Decker O. Comparison of social support and psychosocial stress after heart and liver transplantation. Transplant Proc. 2008:40(4):938-9. https://doi.org/10.1016/j.transproceed. 2008.03.039

12. Bowling A, Rowe $G$, Lambert N, Waddington M, Mahtani $K$. The measurement of patients' expectations for health care: a review and 
psychometric testing of a measure of patients' expectations. Health Technol Assess. 2012;16(30) https://doi.org/10.3310/hta16300.

13. Santos LM, Amorim LD, Santos DN, Barreto ML. Measuring the level of social support using latent class analysis. Soc Sci Res. 2015;50:139-46. https://doi. org/10.1016/.jssresearch.2014.11.009.

14. Lima EDRP, Norman EM, Lima AP. Translation and adaptation of the social support network inventory in Brazil. J Nurs Scholarsh. 2005;37(3):258-60. https://doi.org/10.1111/j.1547-5069.2005.00044.x.

15. Flaherty JA, Gaviria FM, Pathak DS. The measurement of social support: The social support network inventory. Compr Psychiatry. 1983;24(6):521-9. https://doi.org/10.1016/0010-440X(83)90019-6.

16. Gomes-Villas Boas LC, et al. Relationship among social support, treatment adherence and metabolic control of diabetes mellitus patients. Rev LatinoAm Enfermagem. 2012;20(1):52-8. https://doi.org/10.1590/5010411692012000100008

17. Lopes MAL, Lima EDRP. Continuous use of intermittent bladder catheterization-can social support contribute? Rev Latino-Am Enfermagem. 2014;22(3):461-6. https://doi.org/10.1590/0104-1169.3268.2438.

18. Meadows-Oliver M. Social support among homeless and housed mothers: an integrative review. J Psychosoc Nurs Ment Health Serv. 2005;43(2):40-7.

19. Harper FW, Peterson AM, Albrecht TL, Taub JW, Phipps S, Penner LA, et al. Satisfaction with support versus size of network: differential effects of social support on psychological distress in parents of pediatric cancer patients. Psychooncology. 2016;25(5):551-8. https://doi.org/10.1002/pon.3863.

20. Baker DL, Melnikow J, Ly MY, Shoultz J, Niederhauser V, Diaz-Escamilla R Translation of health surveys using mixed methods. J Nurs Scholarsh. 2010; 42(4):430-8. https://doi.org/10.1111/j.1547-5069.2010.01368.x.

21. Cowling T, Jennings LW, Goldstein RM, Sanchez EQ, Chinnakotla S, Klintmalm GB, Levy MF. Liver transplantation and health-related quality of life: scoring differences between men and women. Liver Transpl. 2004;10(1): 88-96. https://doi.org/10.1002/tt.20013.

22. Singal AK, Guturu P, Hmoud B, Kuo YF, Salameh H, Wiesner RH. Evolving frequency and outcomes of liver transplantation based on etiology of liver disease. Transplantation. 2013;95(5):755-60. https://doi.org/10.1097/tp. 0b013e31827afb3a.

23. Scholz U, Klaghofer R, Dux R, Roellin M, Boehler A, Muellhaupt B, Noll G, et al. Predicting intentions and adherence behavior in the context of organ transplantation: gender differences of provided social support. J Psychosom Res. 2012;72(3):214-9. https://doi.org/10.1016/j.jpsychores.2011.10.008.

24. Ferreira $L G$, Anastácio LR, Lima AS, Correia MI. Malnutrition and inadequate food intake of patients in the waiting list for liver transplant. Rev Assoc Med Bras. 2009;55(4):389-93. https://doi.org/10.1590/S0104-42302009000400011.

25. Teixeira HR, Marques DM, Lopes AR, Ziviani LC, Magro JT, Mente ED, CastroE-Silva O, et al. Anxiety and stress levels on liver transplantation candidates. Transplant Proc. 2016;48(7):2333-7. https://doi.org/10.1016/j.transproceed. 2016.06.031.

26. World Health Organization. Global status report on alcohol and health Luxembourg: World Health Organization; 2014. http://www.who.int/ substance_abuse/publications/alcohol_2011/en/. Acessed 07 Jan 2018. ISBN9789240692763

27. Rehm J, Taylor B, Mohapatra S, Irving H, Baliunas D, Patra J, et al. Alcohol as a risk factor for liver cirrhosis: a systematic review and meta-analysis. Drug Alcohol Rev. 2010;29(4):437-45. https://doi.org/10.1111/j.1465-3362.2009.00153.x.

28. Jepsen P, Ott P, Andersen PK, Sørensen HT, Vilstrup H. Clinical course of alcoholic liver cirrhosis: a Danish population-based cohort study. Hepatology. 2010;51(5):1675-82. https://doi.org/10.1002/hep.23500.

29. Riggio O, Ridola L, Pasquale C, Nardelli S, Pentassuglio I, Moscucci F, Merli M. Evidence of persistent cognitive impairment after resolution of overt hepatic encephalopathy. Clin Gastroenterol Hepatol. 2011;9(2):181-3. https://doi.org/10.1016/j.cgh.2010.10.002.

30. Schneekloth TD, Jowsey SG, Biernacka JM, Burton MC, Vasquez AR, Bergquist, et al. Pretransplant psychiatric and substance use comorbidity in patients with cholangiocarcinoma who received a liver transplant. Psychosomatics. 2012; 53(2):116-22. https://doi.org/10.1016/j.psym.2011.11.002.

31. Park J, Kitayama S, Karasawa M, Curhan K, Markus HR, Kawakami N, et al. Clarifying the links between social support and health: culture, stress, and neuroticism matter. J Health Psychol. 2013;18(2):226-35. https://doi.org/10. $1177 / 1359105312439731$.

32. Telles-Correia D, Mega I. Candidates for liver transplantation with alcoholic liver disease: psychosocial aspects. World J Gastroenterol. 2015;21(39): 11027-33. https://doi.org/10.3748/wjg.v21.i39.11027.
33. Ramanan W, Singh SK. A study on alcohol use and its related health and social problems in rural Puducherry, India. J Family Med Prim Care. 2016; 5(4):804-8. https://doi.org/10.4103/2249-4863.201175.

34. Krahn GL. Conceptualizing social support in families of children with special health needs. Fam Process. 1993;32(2):235-48. https://doi.org/10.1111/j.15455300.1993.00235.x.

35. Lin N, Ensel WM. Depression-mobility and its social etiology: the role of life events and social support. J Health Soc Behav. 1984;25(2):176-88.

36. Harris $\Pi$, Thomas CM, Wicks MN, Faulkner MS, Hathaway DK. Subjective burden in young and older African-American caregivers of patients with end stage renal disease awaiting transplant. Nephrol Nurs J. 2000;27(4):383-91.

37. Bajaj JS, Wade JB, Gibson DP, Heuman DM, Thacker LR, Sterling RK, Stravitz RT, Luketic V, Fuchs M, White MB, Bell DE, Gilles H, Morton K, Noble N, Puri $P$, Sanyal AJ. The multi-dimensional burden of cirrhosis and hepatic encephalopathy on patients and caregivers. Am J Gastroenterol. 2011; 106(9):1646-53. https://doi.org/10.1038/ajg.2011.157.

38. Young AL, Rowe IA, Absolom K, Jones RL, Downing A, Meader N, et al. The effect of liver transplantation on the quality of life of the recipient's main caregiver - a systematic review. Liver Int. 2017;37(6):794-801. https://doi. org/10.1111/liv.13333.

39. Morana JG. Psychological evaluation and follow-up in liver transplantation. World J Gastroenterol. 2009;15(6):694-6. https://doi.org/10.3748/wjg.15.694.

40. Santos GG, Gonçalves LC, Buzzo N, Mendes TA, Dias TP, da Silva RC, et al. Quality of life, depression, and pychosocial characteristics of patients awaiting liver transplants. Transplant Proc. 2012;44(8):2413-5. https://doi.org/ 10.1016/j.transproceed.2012.07.046.

\section{Submit your next manuscript to BioMed Central and we will help you at every step:}

- We accept pre-submission inquiries

- Our selector tool helps you to find the most relevant journal

- We provide round the clock customer support

- Convenient online submission

- Thorough peer review

- Inclusion in PubMed and all major indexing services

- Maximum visibility for your research

Submit your manuscript at www.biomedcentral.com/submit
(O) BioMed Central 